\title{
SYNTHESIS AND RP-TLC LIPOPHILICITY EVALUATION OF A NOVEL FLUOCINOLON ACETONIDE SOFT DRUG DERIVATIVE
}

\author{
Vladimir Dobričić*, Sote Vladimirov, Olivera Čudina \\ Department of Pharmaceutical Chemistry, Faculty of Pharmacy, University of Belgrade, \\ 11000 Belgrade, Republic of Serbia \\ *Corresponding author; \\ E-mails: vladimir@pharmacy.bg.ac.rs, sotevlad@pharmacy.bg.ac.rs, \\ ocudina@pharmacy.bg.ac.rs
}

(Received February 2, 2016)

\begin{abstract}
Cortienic acid was obtained by periodic acid oxidation of fluocinolone acetonide, whereas corresponding amide was synthesized from the cortienic acid and ethyl ester of $\beta$-alanine by dicyclohexylcarbodiimide - hydroxybenzotriazole coupling procedure. Lipophilicity of the amide was evaluated by using reversed-phase thin-layer chromatography systems, consisting of ethanol and water in various ratios, and was higher in comparison to fluocinolone acetonide and cortienic acid.
\end{abstract}

Keywords: cortienic acid, amide, lipophilicity, RP-TLC.

\section{INTRODUCTION}

The soft drug concept was presented as part of retrometabolic drug design approach, whose aim was to obtain biologically active compounds with fewer side effects (BODOR et al., 1980; BodOR and KAMINSKI, 1980; STAŃCZAK et al., 2006; PROCOPIOU et al., 2010). The first and second generations of soft glucocorticoids (loteprednol etabonate, etiprednol dicloacetate and corresponding analogues) are cortienic acid derivatives, which are inactive and non-toxic metabolites of traditional glucocorticoids (BODOR and BUCHWALD, 2006; PAVESIO et al., 2008; Chandegara and ChORAwala, 2012). Other glucocorticoid derivatives which are easily metabolized after local administration to non-toxic and inactive metabolites could also be considered soft drugs (antedrugs) (KHAN and LEE, 2008).

Novel amides of cortienic acids (derived from hydrocortisone, prednisolone, methylprednisolone, dexamethasone and betamethasone) and esterified amino acids (methyl and ethyl esters of L-glycine, methyl ester of L-alanine, ethyl ester of $\beta$-alanine and methyl ester of L-phenylalanine) have been recently presented as potentially new soft glucocorticoids for local application to the skin. Their permeability and retention in the skin were predicted by using parallel artificial membrane permeability assay (PAMPA) and biopartitioning micellar chromatography. Quantitative structure - permeability relationship (QSPR) and quantitative structure - retention relationship (QSRR) analyses underlined lipophilicity as a physicochemical property with the highest positive influence on permeability and retention (DOBRIČIĆ et al., 2014; DoBRIČIĆ et al., 2014a). The presence of L-glycine, L-alanine and $\beta$ alanine residues in the $17 \beta$ side chain enables favorable molecule orientation and key binding interactions with amino acids in the glucocorticoid receptor, which was confirmed by good 
local anti-inflammatory activity of these derivatives. Therefore, good local anti-inflammatory activity of novel soft glucocorticoids containing these amino acids in the $17 \beta$ side chain could be expected. Additionally, fewer systemic side effects (in comparison with dexamethasone) and predicted metabolic inactivation indicate that these compounds could be classified as novel soft glucocorticoids (DOBRIČIĆ et al., 2014b).

The aim of this study was to synthesize a new soft glucocorticoid, which is amide of fluocinolone acetonide - derived cortienic acid and ethyl ester of $\beta$-alanine. Lipophilicity of the amide was evaluated by using reversed-phase thin-layer chromatography (RP-TLC) and compared to fluocinolone acetonide and cortienic acid.

\section{MATERIALS AND METHODS}

\section{Chemicals and apparatus}

Fluocinolone acetonide (FA) was purchased from Tokyo Chemical Industry (Tokyo, Japan) and dioxane from Carlo Erba (Rodano, Italy). N-hydroxybenzotriazole (HOBt), N,N'dicyclohexylcarbodiimide (DCC), N,N-dimethylformamide (DMF) and silica gel for preparative thin-layer chromatography were purchased from Sigma Aldrich (Steinheim, Germany), whereas triethylamine (TEA) was bought from Fisher Scientific (Loughborough, UK). $\beta$-alanine ethyl ester hydrochloride and periodic acid were purchased from Acros Organics (Geel, Belgium). Chloroform, ethanol 96\% and methanol were purchased from JT Baker (Loughborough, UK) and acetone was bought from Zorka (Šabac, Serbia). Silica gel for column chromatography and RP-18 modified silica gel TLC plates with $\mathrm{F}_{254}$ fluorescent indicator were purchased from Merck (Darmstadt, Germany).

Melting points were determined by using Boetius PHMK 05 apparatus (Radebeul, Germany). The ${ }^{1} \mathrm{H}$ NMR spectra were recorded on an NMR BRUKER AVANCE III 400 spectrometer (Bruker Biospin $\mathrm{GmbH}$, Rheinstetten, Germany), operating at $400 \mathrm{MHz}$. The accurate masses were determined by using Agilent 6210 Time-of-Flight mass spectrometer (Agilent Technologies, Palo Alto, CA, USA), whereas IR spectra were recorded by using ATR-FTIR spectrometer Nicolet iS10 (Thermo Scientific, Madison, WI, USA). MS/MS analyses were performed on TSQ Quantum Access MAX triple quadrupole mass spectrometer (Thermo Fisher Scientific, San Jose, USA), equipped with heated electrospray ionization source (HESI).

\section{Synthesis of cortienic acid (CFA)}

Fluocinolone acetonide (300 mg, $0.66 \mathrm{mmol}, 1 \mathrm{eq})$ was dissolved in dioxane $(2 \mathrm{~mL})$. Solution of periodic acid in water $\left(275 \mathrm{mg} \mathrm{mL}^{-1}\right)$ was added dropwise $(0.6 \mathrm{~mL}, 0.72 \mathrm{mmol}$ of periodic acid, $1.1 \mathrm{eq})$. The reaction mixture was stirred at room temperature for $20 \mathrm{~h}$ and evaporated to dryness under reduced pressure. The crude product was washed with water (5 $\mathrm{mL})$, dried, washed with chloroform $(12 \mathrm{~mL})$ and dried again.

\section{Synthesis of amide (FAEA)}

CFA (61 mg, $0.14 \mathrm{mmol}, 1 \mathrm{eq})$ was dissolved in DMF (2 $\mathrm{mL})$ and the solution was cooled at $0{ }^{\circ} \mathrm{C}$. Subsequently, DCC (58 mg, $\left.0.28 \mathrm{mmol}, 2 \mathrm{eq}\right)$ and HOBt ( $29 \mathrm{mg}, 0.21 \mathrm{mmol}$, $1.5 \mathrm{eq})$ were added. The mixture was stirred at the same temperature for $1 \mathrm{~h}$ and after that it was maintained at temperature not exceeding $8{ }^{\circ} \mathrm{C}$ for $20 \mathrm{~h}$. $\beta$-alanine ethyl ester hydrochloride (22.2 mg, $0.14 \mathrm{mmol}, 1 \mathrm{eq}$ ) was dissolved in DMF (1 mL), TEA was added (39 $\mu \mathrm{L}, 0.28 \mathrm{mmol}, 2 \mathrm{eq}$ ) and this mixture was cooled at $0^{\circ} \mathrm{C}$. Finally, the mixture of CFA, DCC and HOBt was filtered and added dropwise. The final reaction mixture was stirred at $0^{\circ} \mathrm{C}$ for 1 $\mathrm{h}$ and it was maintained at temperature not exceeding $8{ }^{\circ} \mathrm{C}$ for $20 \mathrm{~h}$. The reaction mixture was 
filtered, evaporated to dryness under reduced pressure and purified by using column chromatography (the mobile phase was chloroform/methanol 99:1 (v/v)). Final purification was performed using preparative thin layer chromatography (the mobile phase was chloroform/methanol 95:5 (v/v)). The purified compound was recrystallized in the mixture of water and methanol.

\section{RP-TLC evaluation of lipophilicity}

The TLC plates were spotted with $1.0 \mu \mathrm{L}$ of freshly prepared solutions of tested compounds in ethanol $\left(1 \mathrm{mg} \mathrm{mL}^{-1}\right)$ and developed by the ascending technique in glass TLC chambers with glass lids. After development, spots were detected under UV light $(\lambda=254 \mathrm{~nm})$. The $R_{F}$ values were calculated according to the equation (1):

$$
R_{F}=\frac{l}{l_{0}}
$$

$l$ - migration distance of tested compound

$l_{0^{-}}$migration distance of solvent front

The $R_{M}$ values were calculated according to the equation (2).

$$
R_{M}=\log \left(\frac{1}{R_{F}}-1\right)
$$

\section{RESULTS}

\section{Synthesis and physico-chemical characterization of CFA}

After purification, white crystalline solid was obtained (127 mg, yield: 44\%, Fig. 1). Melting point: $263.5-266{ }^{\circ} \mathrm{C}$. IR (ATR) $v_{\max }\left(\mathrm{cm}^{-1}\right)$ : 710.64, 728.48, 852.11, 863.13, 913.54, 1054.11, 1161.50, 1172.02, 1254.61, 1376.61, 1385.47, 1612.62, 1603.02, 1661.27, 1711.48, 1722.46, 3409.29. ${ }^{1} \mathrm{H}$ NMR (400 MHz, CD3OD) $\delta \mathrm{ppm} 1.06(3 \mathrm{H}, \mathrm{s}, \mathrm{H}-18), 1.25\left(3 \mathrm{H}, \mathrm{s}, \mathrm{CH}_{3}\right.$ from $\mathrm{C} 16 \alpha, \mathrm{C} 17 \alpha$ side chain), 1.35 (3H, s, $\mathrm{CH}_{3}$ from $\mathrm{C} 16 \alpha, \mathrm{C} 17 \alpha$ side chain), $1.56(5 \mathrm{H}, \mathrm{m}$, $3 \times H-19,2 \times H-12), 1.71(1 \mathrm{H}, \mathrm{m}, \mathrm{H}-7), 1.79(1 \mathrm{H}, \mathrm{d}, \mathrm{J}=13.6 \mathrm{~Hz}, \mathrm{H}-15), 2.07$ (2H, m, H-14, H15), $2.30(1 \mathrm{H}, \mathrm{m}, \mathrm{H}-8), 4.24(1 \mathrm{H}, \mathrm{d}, \mathrm{J}=10 \mathrm{~Hz}, \mathrm{H}-11), 5.52(1 \mathrm{H}, \mathrm{m}, \mathrm{H}-6), 6.27(1 \mathrm{H}, \mathrm{s}, \mathrm{H}-4)$, $6.32(1 \mathrm{H}, \mathrm{dd}, \mathrm{J}=2 \mathrm{~Hz}, \mathrm{~J}=10 \mathrm{~Hz}, \mathrm{H}-2), 7.37(1 \mathrm{H}, \mathrm{d}, \mathrm{J}=10.4 \mathrm{~Hz}, \mathrm{H}-1) . \mathrm{m} / \mathrm{z}=436.9\left(\mathrm{M}^{+}-1\right)$, 334.9, 416.9, 266.8, 294.8, 314.8, 276.8. MS [M+H]+ calculated for $\mathrm{C}_{23} \mathrm{H}_{28} \mathrm{~F}_{2} \mathrm{O}_{6}=438.18539$; observed $=438.18078$.

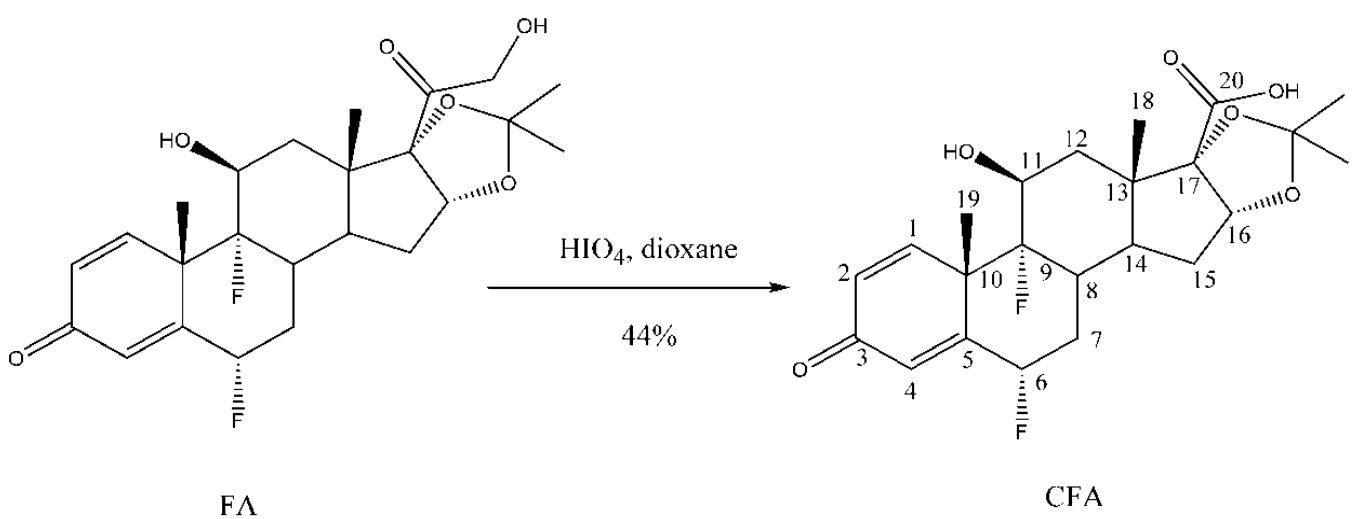

Figure 1. Synthesis of CFA 


\section{Synthesis and physico-chemical characterization of FAEA}

After purification, white crystalline solid was obtained (53 mg, yield: 70\%, Fig. 2). Melting point: $237.2-239.9{ }^{\circ} \mathrm{C}$. IR (ATR) $v_{\max }\left(\mathrm{cm}^{-1}\right)$ : 863.64, 898.23, 993.38, 1030.80, 1044.54, 1061.43, 1193.36, 1351.52, 1376.79, 1520.94, 1635.39, 1671.17, 1723.06, 3441.62. ${ }^{1} \mathrm{H}$ NMR (400 MHz, DMSO-d6) $\delta$ ppm $0.86(3 \mathrm{H}, \mathrm{s}, \mathrm{H}-18), 1.10\left(3 \mathrm{H}, \mathrm{s}, \mathrm{CH}_{3}\right.$ from $\mathrm{C} 16 \alpha$, $\mathrm{C} 17 \alpha$ side chain), $1.19\left(3 \mathrm{H}, \mathrm{t}, \mathrm{J}=7.2 \mathrm{~Hz}, \mathrm{R}-\mathrm{NH}-\mathrm{CH}_{2} \mathrm{CH}_{2} \mathrm{C}(=\mathrm{O}) \mathrm{OCH}_{2} \mathrm{CH}_{3}\right), 1.32\left(3 \mathrm{H}, \mathrm{s}, \mathrm{CH}_{3}\right.$ from $\mathrm{C} 16 \alpha, \mathrm{C} 17 \alpha$ side chain), 1.50 (3H, s, 3xH-19), 1.54 (4H, m, H-7, H-15, 2xH-12), 1.95 $(3 \mathrm{H}, \quad \mathrm{m}, \quad \mathrm{H}-14, \quad 2 \times \mathrm{H}-15), \quad 2.27 \quad(1 \mathrm{H}, \quad \mathrm{m}, \quad \mathrm{H}-8), \quad 4.06 \quad(2 \mathrm{H}, \quad \mathrm{q}, \quad \mathrm{J}=7.2, \quad \mathrm{R}-\mathrm{NH}-$ $\left.\mathrm{CH}_{2} \mathrm{CH}_{2} \mathrm{C}(=\mathrm{O}) \mathrm{OCH}_{2} \mathrm{CH}_{3}\right), 4.16(1 \mathrm{H}, \mathrm{m}, \mathrm{H}-11), 4.94(1 \mathrm{H}, \mathrm{m}, \mathrm{H}-16), 5.43(1 \mathrm{H}, \mathrm{s},-\mathrm{OH}$ at $\mathrm{C}-$ 11), $5.57(1 \mathrm{H}, \mathrm{m}, \mathrm{H}-6), 6.11(1 \mathrm{H}, \mathrm{s}, \mathrm{H}-4), 6.30(1 \mathrm{H}, \mathrm{dd}, \mathrm{J}=2 \mathrm{~Hz}, \mathrm{~J}=10 \mathrm{~Hz}, \mathrm{H}-2), 7.27(1 \mathrm{H}, \mathrm{d}$, $\mathrm{J}=10 \mathrm{~Hz}, \mathrm{H}-1), 7.77\left(1 \mathrm{H}, \mathrm{t}, \mathrm{J}=6 \mathrm{~Hz}, \mathrm{R}-\underline{\mathrm{NH}}-\mathrm{CH}_{2} \mathrm{CH}_{2} \mathrm{C}(=\mathrm{O}) \mathrm{OCH}_{2} \mathrm{CH}_{3}\right) . \mathrm{m} / \mathrm{z}=536.0\left(\mathrm{M}^{+}-1\right)$, $516.1,415.8,395.9,435.8,276.8,427.8$. MS $[\mathrm{M}+\mathrm{H}]+$ calculated for $\mathrm{C}_{28} \mathrm{H}_{37} \mathrm{~F}_{2} \mathrm{NO}_{7}=$ 538.26109 ; observed $=538.26078$.

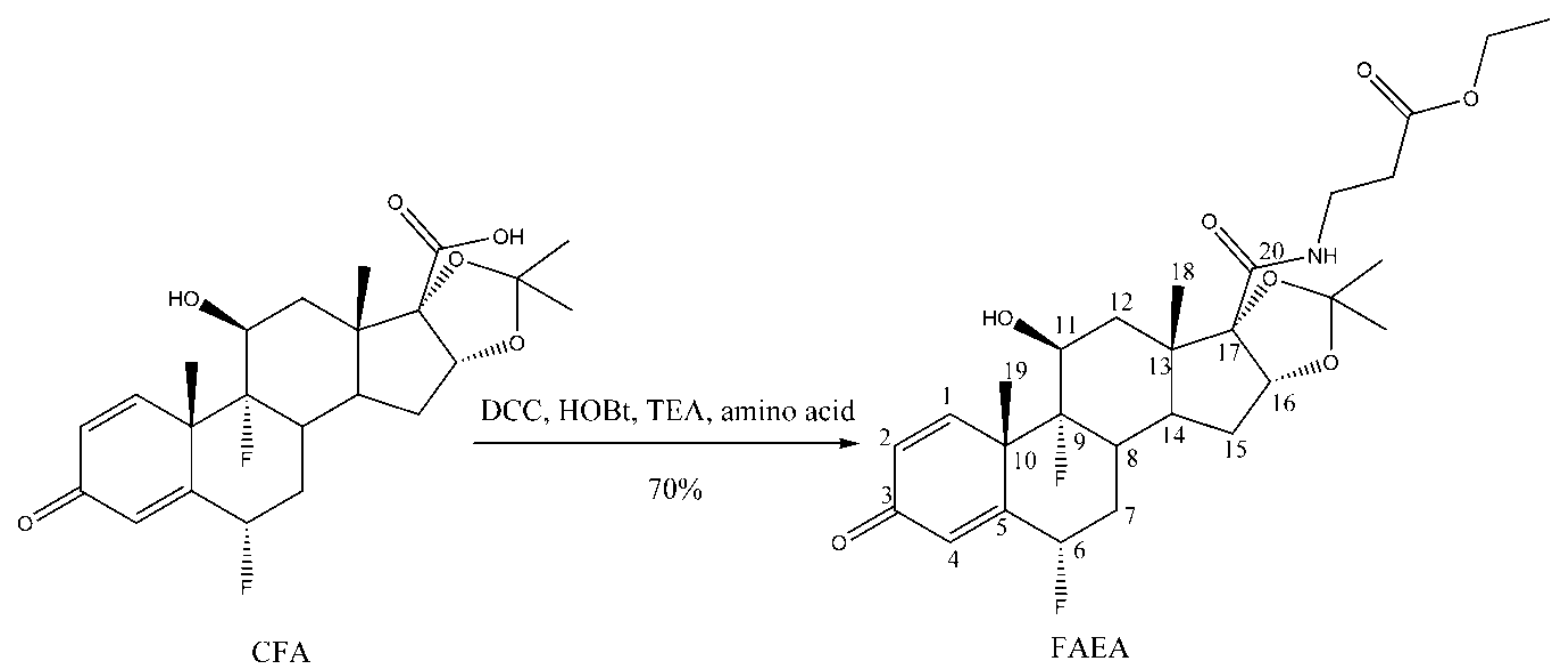

Figure 2. Synthesis of FAEA

\section{RP-TLC evaluation of lipophilicity}

Chromatographic behavior of FAEA, FA (parent glucocorticoid) and CFA (intermediate in the FAEA synthesis and potential metabolite of FAEA) was tested in four RP-TLC systems, consisting of ethanol and water in different ratios: 40:50, 50:50, 60:40 and $70: 30(\mathrm{v} / \mathrm{v})$. For each compound, $\mathrm{R}_{\mathrm{M}}$ values were calculated and plotted against the percentage of ethanol (Fig. 3).

RP-TLC parameters, used for the evaluation of lipophlicity of FA, CFA and FAEA, are presented in Table 1.

Table 1. RP-TLC parameters calculated for FA, CFA and FAEA

\begin{tabular}{lccc}
\hline Compound & $R_{M}^{\circ}$ & $\boldsymbol{a}$ & $C_{\boldsymbol{0}}$ \\
\hline FA & 3.17 & -0.056 & 56.26 \\
\hline CFA & 2.65 & -0.055 & 48.01 \\
\hline FAEA & 3.78 & -0.063 & 59.30 \\
\hline
\end{tabular}



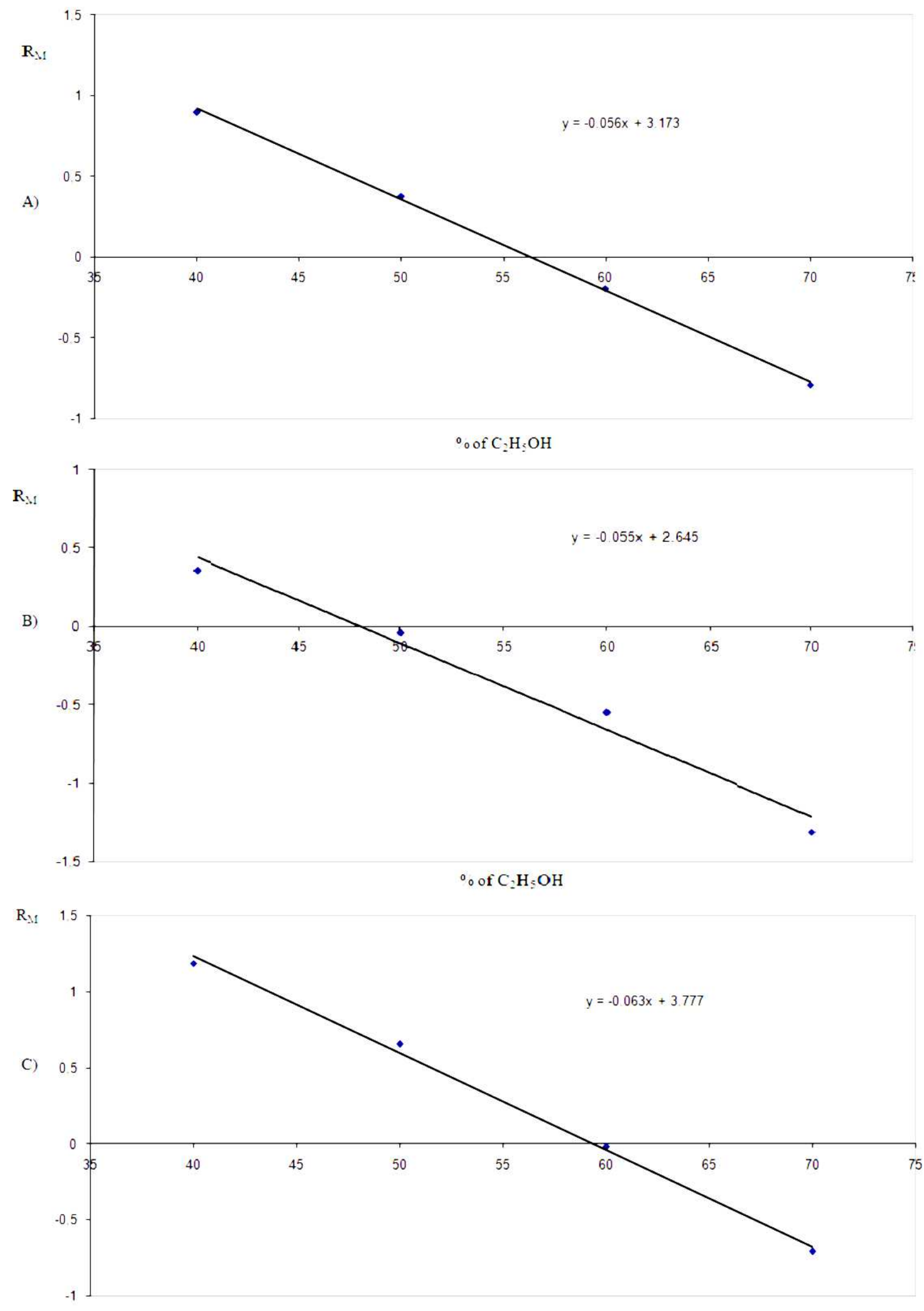

$\circ$ of $\mathrm{C}_{2} \mathrm{H}_{5} \mathrm{OH}$

Figure 3. $\mathrm{R}_{\mathrm{M}}$ values versus the ethanol content; A) FA, B) CFA and C) FAEA 


\section{DISCUSSION}

\section{Synthesis of CFA and FAEA}

Periodic acid oxidation is the most commonly used procedure for the synthesis of cortienic acids. In this study, CFA was synthesized by periodic acid oxidation of fluocinolone acetonide and the highest yield was obtained when dioxane was used as a solvent. Alternatively, oxidation could be performed by introducing air in the solution of fluocinolone acetonide in the presence of potassium-carbonate or by using potassium superoxide (AlvareZ, 1980; ASHTON et al., 1994).

FAEA was synthesized by using two-step DCC-HOBt coupling procedure, which resulted in higher yields than the single-step EDC-HOBt coupling procedure when similar compounds were synthesized (DOBRIČIĆ et al., 2014b). In the first step, CFA was esterified with HOBt (in the presence of DCC) and in the second step FAEA was synthesized in the reaction between CFA-HOBt ester and ethyl ester of $\beta$-alanine (FORMSTECHER et al., 1980).

\section{RP-TLC evaluation of lipophilicity}

The shake flask method, based on partitioning of substances between octanol and water, is considered standard method for the estimation of lipophilicity. However, it is time consuming and requires large amounts of solvents and tested compounds. Alternatively, chromatographic methods (HPLC and TLC) can be used for fast and simple evaluation of lipophilicity of various groups of drugs (MAES et al., 1998; CSERMELY et al., 2008; ODOVIĆ et al., 2009).

RP-TLC parameters used for the estimation of lipophilicity were $C_{0}\left(\mathrm{R}_{\mathrm{M}}\right.$ value when the ethanol content is $0 \%$ (curve intercept)), $a$ (slope of the curve) and $R_{M}^{0}$ (MORAK et al., 2007; STAREKA et al., 2013; BIEGANOWSKA et al., 1995). Correlation coefficients ranged from 0.9889 to 0.9995 , which means there are linear relationships between $R_{M}$ values and ethanol contents. Therefore, $R_{M}^{0}$ can be calculated by extrapolation of the curves to the $y$ axes. Parameter $C_{0}$ is calculated according to the equation (3):

$$
C_{0}=-\frac{R_{M}^{0}}{a}
$$

FAEA has the highest values of $R_{M}^{0}$ and $C_{0}$ and the highest absolute value of $a$, indicating higher lipophilicity of this derivative in comparison with FA and CFA. Therefore, it could also be expected that FAEA has favorable properties for local application to the skin.

\section{CONCLUSION}

Cortienic acid was synthesized by periodic acid oxidation of fluocinolon acetonide (yield: 44\%) and used for the synthesis of amide with ethyl ester of $\beta$-alanine (DCC-HOBt coupling procedure; yield: 70\%). Chromatographic behavior of fluocinolone acetonide, cortienic acid and the amide was tested in RP-TLC systems consisting of ethanol and water in various ratios $\left(40: 50,50: 50,60: 40\right.$ and 70:30 (v/v)). Calculated RP-TLC parameters $\left(R_{M}^{\circ}, a\right.$ and $C_{\mathbf{0}}$ ) indicate that FAEA should have the highest lipophilicity and favorable properties for local skin application. 


\section{Acknowledgment}

This work was financially supported by the Ministry of Education, Science and Technological Development, Belgrade, Serbia, as a part of Project No.172041.

\section{References:}

[1] AlvareZ, F.S. (1980): Chemical process for preparing androsta-4-ene 17 $\alpha$-carboxilic acid. US 4198336 A.

[2] Ashton, M.J., Karlsson, S.J.-A., Vacher, B.Y.J., Withnall, M.T. (1994): New steroids. WO 94/14834.

[3] Bieganowska, M.L., Doraczynska-Szopa, A., Petruczynik, A. (1995): The retention behavior of some sulfonamides on different TLC plates. 2. Comparison of the selectivity of the systems and quantitative determination of hydrophobicity parameters. J. Planar Chromatogr. - Mod. TLC 8: 122-128.

[4] Bodor, N., KAminski, J., SelK, S. (1980): Soft drugs. 1. Labile quaternary ammonium salts as soft antimicrobials. J. Med. Chem. 23: 469-474.

[5] Bodor, N., KAMINSKI, J. (1980): Soft drugs. 2. Soft alkylating compounds as potential antitumor agents. J. Med. Chem. 23: 566-569.

[6] Bodor, N., Buchwald P. (2006): Corticosteroid design for the treatment of asthma: structural insights and the therapeutic potential of soft corticosteroids. Curr. Pharm. Des. 12: 3241-3260.

[7] Chandegara, N., Chorawala, M (2012): Soft and dissociative steroids: a new approach for the treatment of inflammatory airway and eye diseases. Int. J. Pharm. Sci. Res. 3: 311-319.

[8] Csermely, T., Kalasz, H., Deak, K., Hasan, M., Darvas, F., Petroianu, G. (2008): Lipophilicity determination of some ACE inhibitors by TLC. J. Liq. Chromatogr. R. T. 31: 2019-2034.

[9] Dobričić, V., Marković, B., Nikolic, K., Vladimirov, S., Čudina, O. (2014): 17ßcarboxamide steroids - in vitro prediction of human skin permeability and retention using PAMPA technique. Eur. J. Pharm. Sci. 52: 95-108.

[10] Dobričić, V., Nikolic, K., Vladimirov, S., Čudina, O. (2014a): Biopartitioning micellar chromatography as a predictive tool for skin and corneal permeability of newly synthesized 17ß-carboxamide steroids. Eur. J. Pharm. Sci. 56: 105-112.

[11] Dobričić, V., Marković, B., Milenković, N., Savić, V., JaĆević, V., Rančić, N., Vladimirov, S., ČUdinA, O. (2014b): Design, synthesis, and local anti-inflammatory activity of 17ß-carboxamide derivatives of glucocorticoids. Arch. Pharm. 347: 786-797.

[12] Formstecher, P., Lustenberger, P., DautrevauX, M. (1980): Synthesis of steroidal 17ß-carboxamide derivatives. Steroids 35: 265-272.

[13] Khan, M.O.F., LEE, H.J. (2008): Synthesis and pharmacology of anti-inflammatory steroidal antedrugs, Chem. Rev. 108: 5131-5145. 
[14] Maes, P., Formstecher, P., Lustenberger, P., Dautrevaux, M (1998): Highperformance liquid chromatography in the evaluation of the lipophilicity of $17 \beta$ carboxamide steroid derivatives. J. Chromatogr. 445: 409-416.

[15] Morak, B., Nowak, M., Pluta, K. (2007): Determination of the lipophilicity parameters $\mathrm{R}_{\mathrm{M} 0}$ and $\log \mathrm{P}$ of new azaphenothiazines by reversed-phase thin-layer chromatography. J. Liq Chromatogr. R. T. 30: 1845-1854.

[16] Odović, J., Aleksić, M., Stojimirović, B., Milojković-OpsenicA, D., TeŠIĆ, Ž. (2009): Normal-phase thin-layer chromatography of some angyotensin converting enzyme (ACE) inhibitors and their metabolites. J. Serb. Chem. Soc. 74: 677-688.

[17] Pavesio, C. E., DeCory, H. H. (2008): Treatment of ocular inflammatory conditions with loteprednol etabonate. Br. J. Ophthalmol. 92: 455-459.

[18] Procopiou, P.A., Barrett, V.J., Bevan, N.J., Biggadike, K., Box, P.C., Butchers, P.R., Coe, D.M., Conroy, R., Emmons, A., Ford, A.J., Holmes, D.S., Horsley, H., Kerr, F., Li-Kwai-Cheung, A.M., LOOKer, B.E., ManN, I.S., MCLaY, I.M., Morrison, V.S., Mutch, P.J., SMith, C.E., Tomlin P. (2010): Synthesis and structureactivity relationships of long-acting $\beta_{2}$ adrenergic receptor agonists incorporating metabolic inactivation: an antedrug approach. J. Med. Chem. 53: 4522-4530.

[19] Stańczak, A., Ferra, A. (2006): Prodrugs and soft drugs. Pharmacol. Rep. 58: 599613.

[20] StareKA, M., Komsta, Ł. and KrZeK, J. (2013): Reversed-phase thin-layer chromatography technique for the comparison of the lipophilicity of selected nonsteroidal anti-inflammatory drugs. J. Pharmaceut. Biomed. 85: 132-137. 